\title{
Peranan Guru Bimbingan dan Konseling dalam Pelayanan kepada Peserta Didik pada Masa Pendemi Covid-19 di SMP N 7 Muaro Jambi
}

\author{
Parida Ariati \\ SMP Negeri 7 Muaro Jambi, Jambi Indonesia \\ Correspondence email: ariatiparida@gmail.com
}

\begin{abstract}
Abstrak: Guru Bimbingan dan Konseling (BK) seyogyanya mampu menjadi mediator untuk membangun komunikasi yang efektif dan memberikan perhatian pada peserta didik. Selama masa pandemi, guru BK dapat menggunakan bermacam media dan platform komunikasi yang familiar bagi peserta didik, namun tidak mengabaikan nilai humanis dari profesi konselor. Tujuan penelitian ini untuk mengetahui upaya pelayanan guru Bimbingan dan Konseling, respon peserta didik, serta kendala atau hambatan pelayanan Bimbingan dan Konseling selama pandemi COVID-19. Metode penelitian yang digunakan adalah fenomenologi diskriptif. Hasil penelitian didapatkan layanan Bimbingan dan Konseling yang di berikan selama pandemi COVID19 di SMPN 7 Muaro Jambi menggunakan layanan bimbingan klasikal. Adapun respon atau perasaan peserta didik dalam pelayanan guru Bimbingan dan Konseling selama pandemi COVID-19 berbeda-beda masing-masing subyek penelitian, dan kendala atau hambatan berupa ada beberapa peserta didik yang tidak memiliki handphone, biaya yang kurang memadai untuk paket data, dan jaringan telephon yang lelet sehingga peserta didik menjadi terganggu dalam pembelajaran. Saran bagi orang tua hendaknya meluangkan waktu, mendukung, dan menyayangi anak di lingkungan rumah, karena anak biasanya memerlukan perhatian dan dukungan dari masing-masing orang tuanya. Saran bagi masyaraka tapabila kita mendapat musibah atau bencana hendaknya di tanggapi dengan sabar dan ikhlas menerimanya, tentunya juga memperhatikan peraturan yang di buat oleh pemerintah agar pandemi COVID-19 dapat berakhir. Saran bagi peneliti untuk penelitian selanjutnya harus di perhatikan dan disiapkanapa yang di perlukan dalampenelitian.
\end{abstract}

Kata Kunci :Pelayanan; Bimbingan dan Konseling; COVID-19

\begin{abstract}
Guidance and Counseling (BK) teachers should be able to become a mediator to build effective communication and pay attention to students. During the pandemic, counseling teachers can use various media and communication platforms that are familiar to students, but do not ignore the humanist value of the counselor profession. The purpose of this study was to determine the efforts of Guidance and Counseling teacher services, student responses, as well as obstacles or obstacles to Guidance and Counseling services during the COVID-19 pandemic. The research method used is descriptive phenomenology. The results of the study were that the Guidance and Counseling services provided during the COVID-19 pandemic at SMPN 7 Muaro Jambi used classical guidance services. The responses or feelings of students in the Guidance and Counseling teacher services during the COVID-19 pandemic were different for each research subject, and the obstacles or obstacles were that there were some students who did not have cellphones, insufficient costs for data packages, and networks. telephone is slow so that students become distracted in learning. Suggestions for parents should be to spend time, support, and love their children in the home environment, because children usually need the attention and support of each parent. Suggestions for the community if we have a disaster or disaster should be responded to patiently and sincerely to accept it, of course also pay attention to the regulations made by the government so that the COVID-19pandemic can end. Suggestions for researchers for further research must be considered and prepared what is needed in research.
\end{abstract}

Keywords: Service; Guidance and counseling; COVID-19

\section{PENDAHULUAN}

Pada akhir tahun 2019, seluruh dunia digemparkan dengan munculnya suatu penyakit/wabah yang disebabkan oleh Corona Virus Disease 2019 atau Covid-19. Virus ini pertama kali muncul di Wuhan, salah satukota di Cina, kemudian menyebar keseluruh penjuru dunia dan menjadi pandemi yang serius. Virus ini menyebabkan penyakit saluran pernapasan yang mirip dengan flu biasa dan dapat menular melalui kontak fisik dengan orang-orang yang terinfeksi.Virus inimenyebabkan penularan begitu cepat dan sulitnya mendeteksi orang yang terinfeksi dikarenakan masa inkubasi covid -19 kurang lebih dua pekan menyebabkan banyaknya korban jiwa yang berjatuhan. Penularan melalui kontak antar manusia yang sulit diperkirakan karena kegiatan sosial yang sulit dihindari merupakan peyebab terbesar menyebarnya virus ini. Melalui konferensi Pers pada tanggal 11 Maret 2020 Organisasi Kesehatan Dunia (WHO) telah mengumumkan bahwa virus corona yang tengah merebak saat ini sebagai pandemi global dan Badan Nasional Penanggulangan Bencana (BNPB) menetapkan status darurat Nasional berkaitan dengan kondisi tersebut.

Sistem pembelajaran daring(dalam jaringan) merupakan sistem pembelajaran tanpa tatap muka secara langsung antara guru dan siswa tetapi dilaksanakan melalui perangkat compute ratau laptop yang terhubung dengan koneksi jaringan internet. Guru dapat melakukan pembelajaran bersamadiwaktu yang sama menggunakan grup dimedia social seperti WhatsApp (WA), telegram, instagram, aplikasi zoom, google classroom ataupun media lainnya sebagai media 
Parida Ariati, Peranan Guru Bimbingan dan Konseling dalam Pelayanan kepada Peserta Didik pada Masa Pendemi Covid-19 di SMP N 7 Muaro Jambi

pembelajaran

Guru harus memastikan kegiatan belajar mengajar tetap berjalan, meskipun siswa berada di rumah. Disinilah peran Guru Bimbingan dan Konseling (BK) dalam membangun komunikasi danmemberikan perhatian pada peserta didik, mengatasi permasalahan-permasalahan siswa selama pembelajaran daring. Bimbingan dan Konseling (BK) adalah proses pemberian bantuan oleh seorang yang ahli yang disebut sebagai konselor kepada konseli atau klien dengan tujuan agar konseli atau klien memiliki kemampuan memahami dan mengarahkan diri, menyesuaikan diri serta memecahkan masalah yang dihadapi, sehingga konseli atau klien dapat bertindak dengan wajar sesuai dengan tuntutan lingkungannya.

Guru BK professional salah satunya cirinya mampu mengelola strategi layanan konseling dengan baik. Namun, Guru BK perlu untuk mengenal dan menggunakan kecanggihan teknologi untuk dapat menjalankan peran mereka sebagai mediator antara sekolah dengan murid juga orang tuanya. Kebutuhan akan guru bimbingan dan konseling profesional memberikan tantangan sekaligus sebuah peluang bagi pengembangan diri guru bimbingan dan konseling. Kantor berita online, careerbuilder.co.uk (dalam Yusri, 2013) menulis dan menempatkan guru bimbingan dan konseling/konselor sekolah dalam 10 besar profesi yang sangat dibutuhkan di dalam masyarakat saat ini. Untuk dapat bersaing di pasar global guru bimbingan dan konseling diharapkan selalu mengembangkan kemampuan profesional dibidangnya. Seorang guru bimbingan dan konseling profesional dituntut untuk terus mengembangkan kompetensinya sesuai dengan kebutuhan, tuntutan masyarakat, dan perkembangan zaman.

Pendidikan merupakan suatu sarana membentuk pribadi manusia menjadi yang lebih baik, memberikan pelajaran mengenai tata krama, norma norma sosial dan lain sebagainya agar dapat dibawa pada lingkungan kehidupan social dimasa kini dan akan datang. Landasan hukum yang membahas perundang-undangan pendidikan di Indonesia memberikan konsep pendidikan harus berakar pada kebudayaan nasional. Di dalamUndang- Undang Nomor 20 Tahun 2003 mengenai Sistem Pendidikan, menyebutkan bahwa: Pendidikan nasional berfungsi mengembangkan kemampuan dan membentuk watak serta peradaban bangsa yang bermartabat dalam rangka mencerdaskan kehidupan bangsa.

Pada dasarnya manusia tidak lepas dari berbagai permasalahan baik orang dewasa yang berkerja, remaja yang menuntut pendidikan, bahkan anak-anak yang baru tumbuh besar mempunyai masalah mereka tersendiri baik itu besar atau kecil. Khususnya di lingkungan sekolah juga dapat kita temukan masalah- masalah yang ada pada anak didik. Terlebih itu masalah kepribadian yang menyangkut dari aspek dalam diri anak didik, ada juga menyangkut berhubungan satu sama lain atau sering kita sebut bersosialisasi, dan menentukan arah masa depan mereka atau karir mereka untuk menunjang masa depannya. Menurut Siregar, \& Nara, (dalam Priyayi., Keliat., \&Hastuti, 2018) mengelompokkan masalah belajar menjadi 2 hal, yaitu masalah belajar internal dan masalah belajar eksternal. Masalah belajar internal merupakan masalah yang timbul dari diri siswa. Misalnya berkaitan dengan kesehatan, rasa aman, kemampuan intelektual, motivasi, usia, jenis kelamin, latar belakang sosial, kebiasaan belajar, kemampuan mengingat, dan kemampuan pengindraan, sedangkan masalah belajar eksternal adalah masalah-masalah yang timbul dari luar diri siswa.

Misalnya terkait dengan kebersihan, udara, ruang belajar, alat belajar, dan lingkungan sosial. Sekarang ini kita menghadapi permasalahan yang tidak hanya mencakup lingkungan sekolah, tetapi termasuk permasalahan di berbagai negara di belahan dunia, dari paparan data WHO, 1 Maret 2020 atau Perhimpunan Dokter Paru Indonesia (PDPI) pada akhir desember tahun 2019 (dalam Yuliana, 2020) sampai saat ini sudah dipastikan terdapat 65 negara yang terjangkit corona virus atau virus COVID-19. Menurut Susilo, dkk, (2020) Coronavirus adalah virus RNA dengan ukuran partikel 120-160 nm. Virus ini utamanya menginfeksi hewan, termasuk di antaranya adalah kelelawar dan unta. Sebelum terjadinya wabah COVID-19, ada 6 jenis corona virus yang dapat menginfeksi manusia, yaitu alpha corona virus 229E, alpha corona virus NL63, beta corona virus OC43, beta corona virus HKU1, Severe Acute Respiratory Illness Coronavirus (SARS-CoV), dan Middle East Respiratory Syndrome Coronavirus (MERS-CoV).

Selama masa Pembatasan Sosial Berskala Besar (PSBB) baik anggota pemerintah, pegawai kator atau swasta, guru-guru di liburkan, dan apabila ketahuan melanggar akan di berikan sangsi atau pun hukuman sesuai pasal tersebut. Menanggapi peraturan pemerintah tentang Pembatasan Sosial Berskala Besar (PSBB) yang terjadi sekarang, sebagai calon konselor atau guru Bimbingan dan Konseling yang professional sudah menjadi tugas kita menyelesaikan permasalahan anak didik, dan memberikan layanan Bimbingan dan Konseling yang membantu anak didik mengoptimalkan kemampuan yang dimiliki serta melonggarkan permasalahan yang mereka hadapi sesuai dengan pendapat Nurhayati, \&Nurfarida, (2018:) layanan bimbingan dan konseling dalam upaya membantu peserta didik atau konseli mencapai tugas perkembangan diri yang optimal, mandiri, sukses, sejahtera dan bahagia dalam kehidupannya. Agar tujuan tersebut tercapai diperlukan kolaborasi dan sinergisitas kerja antara konselor atau guru bimbingan dan konseling, guru matapelajaran, pimpinan sekolah atau madrasah, staf administrasi, orang tua, dan pihak lain yang dapat membantu kelancaran proses dan pengembangan peserta didik atau konseli secara utuh dan optimal dalam bidang pribadi, sosial, belajar, dan karir.

Perlunya guru Bimbingan dan Konseling dalam membantu permasalahan siswa di sekolah, dalam 
Parida Ariati, Peranan Guru Bimbingan dan Konseling dalam Pelayanan kepada Peserta Didik pada Masa Pendemi Covid-19 di SMP N 7 Muaro Jambi

menyelesaikan permasalahan guru Bimbingan dan Konseling perlu mengetahui jenis permasahannya, sesuai dengan pendapat menurut Wendari, Badrujaman, \& Sismiati, (2016) dalam proses mengentaskan permasalahan siswa, guru Bimbingan dan Konseling harus terlebih dahulu mengetahui jenis permasalahan siswa dan melakukan analisis kebutuhan berdasarkan data yang konkret dan validitas dari data tersebut dapat dipertanggungjawabkan. Sehingga, permasalahan yang dilakukan siswa dapat diselesaikan dengan segera secara efektif dan efisien, pencegahan dapat dilakukan sedini mungkin, dan siswa dapat berkembang sesuai dengan tugas perkembangannya.

Layanan Bimbingan dan Konseling dalam upaya membantu siswa atau konseli membantu menyelesaikan permasalahan dan mencapai tugas perkembangan diri yang optimal, mandiri, sukses, sejahtera dan bahagia dalam kehidupannya. Fakta di lapangan berdasarkan penelitian dengan cara observasi dan wawancara terhadap guru Bimbingan dan Konseling di SMPN 7 Muaro Jambi sebelum pandemi COVID-19 guru matapelajaran dan siswa melakukan pembelajaran seperti biasanya yang dilakukan sekolah lain, dalam ranah Bimbingan dan Konseling, guru Bimbingan dan Konseling melaksanakan pelayanan seperti layanan konseling individual, layanan konseling kelompok, layanan bimbingan kelompok, layanan bimbingan klasikal, dan home visit, namun setelah pandemi COVID-19 sebagian ditemukan beberapa guru saja yang berada di sekolah tentunya guru dan siswa kesulitan dalam melakukan pembelajaran di rumah selama pandemi COVID-19, dan juga terkhusus bagi guru Bimbingan dan Konseling yang kebingungan dalam pemberian layanan Bimbingan dan Konseling, dan juga siswa tidak berada dilingkungan sekolah melaksanakan pembelajaran, semenjak di terapkannya Pembatasan Sosial Berskala Besar (PSBB) khususnya di lingkungan persekolahan di Indonesia di liburkan, Kehawatiran guru-guru dan siswa di sekolah tentang kasus pandemi COVID-19 menurut paparan dari Susilo, dkk, (2020) COVID19 pertama dilaporkan di Indonesia pada tanggal 2 Maret 2020 sejumlah 2 kasus. Data 31 Maret 2020 menunjukkan kasus yang terkonfirmasi berjumlah 1.528 kasus dan 136 kasus kematian. Tingkat mortalitas COVID-19 di Indonesia sebesar 8,9\%, angka ini merupakan yang tertinggi di Asia Tenggara.

Sehingga pelaksanaan pendidikan selama pandemi COVID-19, guru-guru di sebagian sekolah ada yang tetap melaksanakan pembelajaran, tetapi secara tidak langsung, dalam artian pembelajaran secara media online atau pembelajaran (daring). Menurut Pakpahan, \&Fitriani, (2020) pembelajaran online adalah system belajar yang terbuka dan tersebar dengan menggunakan perangkat pedagogi (alat bantu pendidikan), yang dimungkinkan melalui internet dan teknologi berbasis jaringan untuk memfasilitasi pembentukan proses belajar dan pengetahuan melalui aksi dan interaksi yang berarti. Tentunya pembelajaran secara media online atau pembelajaran (daring) juga berpengaruh pada guru-guru lainnya terkhusus guru Bimbingan dan Konseling.

\section{METODE}

Metode penelitian menggunakan kualitatif, desain penelitian ini menggunakan fenomenologi. Fenomenologi adalah studi tentang pengetahuan yang dating dari kesadaran (consciousness), atau cara seseorang memahami objek dan kejadian dengan mengalaminya secara sadar. Melihat objek atau kejadian melalui persepktif individu yang mengalaminya. Littlejohn, (dalamPrianti, 2011). Fenomenologi adalah pendekatan yang dimulai oleh Edmund Husserl dan dikembangkan oleh Martin Heidegger untuk memahami atau mempelajari pengalaman hidup manusia. Fokus umum penelitian ini untuk memeriksa atau meneliti esensi atau struktur pengalaman kedalam kesadaran manusia. Tuffour (dalam Helaluddin, 2018). Menurut Hegel (dalam Prianti, 2011) menjelaskan bahwa fenomenologi mengacu pada pengetahuan yang muncul pada kesadaran, ilmu yang menggambarkan apa yang diterima seseorang, dirasakan dan diketahui seseorang dalam kesadaran dan pengalaman seseorang.

Menurut Creswell, \& Moustakas, (dalamNuryana, Pawito, \&Utari2 019:22) adapun tahap atau prosedur dalam melaksanakan studi fenomenologi, yaitu : 1) Menetapkan lingkup fenomena yang akan diteliti : peneliti berusaha memahami perspektif filosofis di balik pendekatan yang digunakan, terutamakonsep mengenai kajian bagaimana orang mengalami sebuah fenomena. Peneliti menetapkan fenomena yang hendak dikaji melalui para informan, 2) Menyusun daftar pertanyaan : peneliti menuliskan pertanyaan penelitian yang mengungkap makna pengalaman bagi para individu, serta menanyakan kepada mereka untuk menguraikan pengalaman penting setiap harinya, 3) Pengumpulan data : peneliti mengumpulkan data dariindividu yang mengalami fenomenayang diteliti. Data diperoleh melalui wawancara yang cukup lama dan mendalam dengan sekitar 5-25 orang. Jumlah ini bukan ukuran baku. Bisa saja subjek penelitiannya hanya 1 orang. Teknik pengumpulan data lain yang dapat digunakan: observasi (langsung dan partisipan), penelusuran dokumen, 4) Tahap Cluster of Meaning : Selanjutnya peneliti mengklasifikasikan pernyataan- pernyataan tadi kedalam tema-tema atau unit-unit makna, serta menyisihkan penyataan yang tumpang tindih atau berulang-ulang. Pada tahap ini, dilakukan: 1) Textural description (deskripsitekstural), peneliti menulis kanapa yang dialami, yakni deskripsi tentang apa yang dialami individu, 2) Structural description (deskripsistruktural), peneliti menuliskan bagaimana fenomena itu dialami oleh para individu. 3) Tahap deskripsi esensi, peneliti mengonstruksi (membangun) deskripsi menyeluruh mengenai makna dan esensi pengalaman para subjek, dan 4) Peneliti melaporkan hasil penelitiannya. Laporan ini memberikan pemahaman yang lebih baik kepada pembaca tentang bagaimana seseorang mengalami sesuatu fenomena. Laporan penelitian menunjukkan adanya kesatuan 
Parida Ariati, Peranan Guru Bimbingan dan Konseling dalam Pelayanan kepada Peserta Didik pada Masa Pendemi Covid-19 di SMP N 7 Muaro Jambi

makna tunggal dari pengalaman, di mana seluruh pengalaman itu memiliki "struktur" yang penting.

\section{HASIL DAN PEMBAHASAN}

Hasil Wawancara dari Guru Bimbingan dan Konseling Nara sumber Pertama Hasil wawancara dari ibu Siti Supriyah, S.Pd, salah satu guru Bimbingan dan Konseling pada 20 Agustus2020 jam 10:00Wib, beliau menjelaskan pelaksanan layanan Bimbingan dan Konseling selama pandemi COVID-19 di SMPN 7 Muaro Jambi berjalan dengan lancar, meski ada beberapa kendala di antaranya guru Bimbingan dan Konseling tidak bisa bertemu langsung dengan siswanya, namun tetap bisa di atasi oleh guru Bimbingan dan Konseling. Langkah- langkah pelayanan Bimbingan dan Konseling sebelum pandemi COVID-19 di SMPN 7 Muaro Jambi di antaranya sesaui dengan prosedur Bimbingan dan Konseling dari guru mata pelajaran menemukan siswa yang mempunyai masalah, kemudian ke guru wali kelas siswa yang menjadi tanggung jawab guru tersebut, kemudian ke arah guru Bimbingan dan Konseling untuk membantu atau

Meringankan permasalahan siswa, kemudian ke arah kesiswaan apakah siswa tersebut ada perubahan atau tidak, setelah itu kalau tidak perubahan di siswa biasanya di serahkan kepala sekolah. Layanan Bimbingan dan Konseling yang di berikan sebelum pandemi COVID-19 di SMPN 7 Muaro Jambi biasanya berupa layanan bimbingan klasikal, layanan bimbingan kelompok, layanan konseling individual, layanan mediasi, dan layanan alih tangan kasus. Tata cara atau langkah- langkah pelayanan Bimbingan dan Konseling setelah pandemi COVID-19 di SMPN 7 Muaro Jambi, masih di rencanakan karena belum ada kasus yang di temukan, sebab sekolah belum aktif sepenuhnya. Layanan Bimbingan dan Konseling yang di berikan setelah pandemi COVID-19 di SMPN 7 Muaro Jambi diantaranya berupa layanan bimbingan klasikal sesuai pedoman Bimbingan dan Konseling yang ada dengan beberapa tahapan pertama awalan atau pendahuluan pada tahapan ini guru Bimbingan dan Konseling memberikan salam serta memberikan penjelasan tentang topik yang akan di jelasakan, tahapan kedua adalah tahap inti atau kegiatan pada tahap ini guru Bimbingan dan Konseling menjelaskan isi materi yang di bawakan serta mengadakan sesi tanya jawab, dan pada tahapan ketiga tahap akhiran atau penutup guru Bimbingan dan Konseling serta bertanya kembali kepada siswa, untuk mengetahui seberapa siswa mengerti tentang materi yang di sampaikan.

Pendapat guru Bimbingan dan Konseling di SMPN 7 Muaro Jambi tentang pembelajaran daring atau online selama pandemi COVID-19 di anggap kurang efektif, karena sulit untuk membentuk karakter siswa secara langsung. Pelayanan Bimbingan dan Konseling yang di berikan selama pembelajaran daring atau online selama pandemi COVID-19 di SMPN 7 Muaro Jambi layanan klasikal dalam bentuk media classroom, dengan cara guru Bimbingan dan Konseling mengatur jam untuk melaksanakan layanan, kemudian siswa- siswa kelas tertentu di perislahkan untuk memasuki classroom yang telah di sediakan sebelumnya oleh guru Bimbingan dan Konseling, kemudian pelayanan bimbingan klasikal di laksanakan untuk membahas topik tertentu yang telah di sediakan oleh guru Bimbingan dan Konseling.

Siswa yang di berikan layanan Bimbingan dan Konseling pembelajaran daring atau online selama pandemi COVID-19 di SMPN 7 Muaro Jambi semua siswa baik itu kelas 7, kelas 8, dan kelas 9. Waktu atau durasi pelaksanaan layanan Bimbingan dan Konseling yang di berikan selama pembelajaran daring atau online selama pandemi COVID-19 di SMPN 7 Muaro Jambi biasanya berlangsung sekitar 30 menit dalam 1 kali daring. Hambatan atau kendala dalam pelaksanaan layanan Bimbingan dan Konseling selama pandemi COVID- 19 di SMPN 7 Muaro Jambi adalah kuota siswa yang terbatas, dan ada beberapa siswa yang masih belum memiliki handphon, ada juga para siswa meminjam handphone milik kakaknya atau milik orang tua.

Saran dan kesan guru Bimbingan dan Konseling tentang pelayanan Bimbingan dan Konseling selama pandemi COVID-19 agar semoga pandemi COVID-19 segera berlalu, dan dunia pendidikan kembali seperti biasanya.Hasil Dokumentasi dari Guru Bimbingan dan Konseling Narasumber Pertama Hasil dokumentasi dari ibu Siti Supriyah, S.Pdbeliau selaku guru Bimbingan dan Konseling di SMPN 7 Muaro Jambi adalah RPL dari pelayanan bimbingan klasikal yang di laksanakan, pedoman wawancara untuk guru Bimbingan dan Konseling, dan berupa foto-foto lingkungan sekolah, serta kegiatan wawancara kepada ibu guru Bimbingan dan Konseling, Hasil Wawancara dari Guru Bimbingan dan Konseling Narasumber Kedua Hasil wawancara dari ibu Dina Sosilawati, S.Pd, guru Bimbingan dan Konseling di SMPN 7 Muaro Jambi 21 Agustus2020 jam 10:00Wib, belau menjelaskan pelaksanan layanan Bimbingan dan Konseling selama pandemi COVID-19 di SMPN 7 Muaro Jambi berjalan dengan lancar, meski ada beberapa kendala di antaranya guru Bimbingan dan Konseling kesulitan dalam menghubungi siswa, dan juga tidak tahu apakah siswanya memperhatikan atau tidak saat guru Bimbingan dan Konseling memberikan layanan. Langkahlangkah pelayanan Bimbingan dan Konseling sebelum pandemi COVID-19 di SMPN 7 Muaro Jambi diantaranya sesuai dengan prosedur Bimbingan dan Konseling dari guru mata pelajaran menemukan siswa yang mempunyai masalah, kemudian ke guru wali kelas siswa yang menjadi tanggung jawab guru tersebut, kemudian ke arah guru Bimbingan dan Konseling untuk membantu atau meringankan permasalahan siswa, kemudian ke arah kesiswaan apakah siswa tersebut ada perubahan atau tidak, setelah itu kalau tidak perubahan di siswa biasanya di serahkan kepala sekolah.

Layanan Bimbingan dan Konseling yang di berikan sebelum pandemi COVID-19 di SMPN 7 Muaro Jambi 
Parida Ariati, Peranan Guru Bimbingan dan Konseling dalam Pelayanan kepada Peserta Didik pada Masa Pendemi Covid-19 di SMP N 7 Muaro Jambi

biasanya berupa layanan bimbingan klasikal, layanan bimbingan kelompok, layanan konseling individual, layanan mediasi, dan layanan alih tangan kasus.

Tata cara atau langkah-langkah pelayanan Bimbingan dan Konseling setelah pandemi COVID19 di SMPN 7 Muaro Jambi, masih di rencanakan karena belum ada kasus yang di temukan, sebab sekolah belum aktif sepenuhnya. Layanan Bimbingan dan Konseling yang di berikan setelah pandemi COVID-19 di SMPN 7 Muaro Jambi diantaranya berupa layanan bimbingan klasikal, sesuai pedoman Bimbingan dan Konseling yang ada dengan beberapa tahapan pertama awalan atau pendahuluan, tahap inti atau kegiatan, dan tahap akhiran atau penutup.

Pendapat guru Bimbingan dan Konseling di SMPN 7 Muaro Jambi tentang pembelajaran daring atau online selama pandemi COVID-19 di anggap kurang efektif, karena sulit untuk membentuk karakter siswa secara langsung. Pelayanan Bimbingan dan Konseling yang di berikan selama pembelajaran daring atau online selama pandemi COVID-19 di SMPN 7 Muaro Jambi adalah layanan klasikal dalam bentuk media classroom, dengan cara guru Bimbingan dan Konseling mengatur jam untuk melaksanakan layanan, kemudian siswa-siswa kelas tertentu di perislahkan untuk memasuki classroom yang telah di sediakan sebelumnya oleh guru Bimbingan dan Konseling, kemudian pelayanan bimbingan klasikal di laksanakan untuk membahas topik tertentu yang telah di sediakan oleh guru Bimbingan dan Konseling.

Siswa yang di berikan layanan Bimbingan dan Konseling pembelajaran daring atau online selama pandemi COVID-19 di SMPN 7 Muaro Jambi semua siswa baik itu kelas 7, kelas 8, dan kelas 9. Waktu atau durasi pelaksanaan layanan Bimbingan dan Konseling yang di berikan selama pembelajaran daring atau online selama pandemi COVID-19 di SMPN 7 Muaro Jambi biasanya berlangsung sekitar 30 menit dalam 1 kali daring. Hambatan atau kendala dalam pelaksanaan layanan Bimbingan dan Konseling selama pandemi COVID- 19 di SMPN 7 Muaro Jambi adalah kouta siswa yang terbatas, dan ada beberapa siswa yang masih belum memiliki handphone, ada juga para siswa meminjam handphone milik kakaknya atau milik orang tua, serta gangguan jaringan internet.

Pendapat atau respon siswa tentang layanan Bimbingan dan Konseling selama pandemi COVID19, berjalan baik, memberikan saran, dan masukkan untuk menjaga kebersihan baik berupa memakai masker ketika keluar rumah, dan selalu mencuci tangan sebelum makan, Bentuk pelayanan Bimbingan dan Konseling yang di laksanakan selama pandemi COVID-19 dengan cara ibu guru Bimbingan dan Konseling memberikan layanan bimbingan klasikal dengan baik untuk anak muridnya, dan memberikan tugas untuk mengetahui seberapa siswa paham tentang materi yang di jelaskan, Pelayanan Bimbingan dan Konseling selama pandemi COVID-19 melibatkan guru-guru Bimbingan dan Konseling, Pelaksanaan layanan Bimbingan dan Konseling selama pandemi COVID-19 terjadi setiap pelajaran Bimbingan dan Konseling sesuai jadwal kelas, Waktu atau durasi siswa menerima layanan Bimbingan dan Konseling yang di berikan selama pandemi COVID-19 di SMPN 7 Muaro Jambi selama pembelajaran Bimbingan dan Konseling 30 menit.

Hambatan atau kendala yang di temukan siswa dalam kegiatan layanan Bimbingan dan Konseling selama pandemi COVID-19 adalah baik berupa jaringan internet yang lelet sehingga siswa menjadi terganggu dalam pembelajaran, Pelayanan Bimbingan dan Konseling berjalan dengan kurang efektif selama pandemi COVID-19, karenamenurut siswa ibu Bimbingan dan Konseling jarang memberikan layanan kepada anak murid di classroom, salah satu faktornya disebabkan waktu yang terbatas dengan guru-guru lain atau pun hambatan lain dalam menghubungi siswanya, Saran dan kesan kamu tentang pelayanan Bimbingan dan Konseling selama pandemi COVID19, menurut siswa ibu guru Bimbingan dan Konseling memberikan penjelasan kepada murid sehingga paham, dan selalu sabar dalam meladeni murid muridnya, dan selalu bersikap baik kepada setiap murid- muridnya, Hasil Dokumentasi dari Siswa Narasumber Pertama Hasil dokumentasi dari Mira Cantika selaku siswa di SMPN 7 Muaro Jambi adalah pedoman wawancara siswa, dan foto-foto hasil wawancara siswa menggunakan viaonline atau aplikasi WhatApp, Hasil Wawancara dari Siswa Narasumber Kedua Hasil wawancara dari Berry Irawan, salah satu siswa di SMPN 7 Muaro Jambi pada tanggal 1 September 2020 waktu 11:00 Wib, peneliti menanyakan perasaan selama pandemi COVID-19 terjadi, siswa merasa cukup bingung, ketika ada tugas di sekolah memahami sesuatu materi lambat ketika selama pelajaran online, tidak sebaikpembelajaran secara langsung yang di jelaskan secara face to face, Pelayanan Bimbingan dan Konseling sebelum pandemi COVID-19 sudah cukup jelas, sangat bermanfaat pelayanan Bimbingan dan Konseling, Pelayanan yang diketahui siswa tentang Bimbingan dan Konseling di sekolah SMPN 7 Muaro Jambi adalah layanan bimbingan klasikal, Pendapat atau respon siswa terhadap layanan Bimbingan dan Konseling selama pandemi COVID19, sangat bermanfaat untuk layanan Bimbingan dan Konseling ini, karena membimbing muridnya dengan sangat sabar di pandemi COVID-19 saat ini, Bentuk pelayanan Bimbingan dan Konseling yang di laksanakan selama pandemi COVID-19, siswa merasa guru Bimbingan dan Konseling meresfon cepat ketika ada murid yang bertanya atau pun kurang paham dengan sesuatu hal yang berada di dalam pelajaran, serta guru Bimbingan dan Konseling bersikap untuk lebih akrab mengayomi siswa,.

Pelayanan Bimbingan dan Konseling selama pandemi COVID-19 melibatkanguru Bimbingan dan Konseling, Pelaksanaan layanan Bimbingan dan Konseling selama pandemi COVID-19 terjadi setiap saat apabila siswa membutuhkan atau pun ketika kita adamasalah dengan keadaan pribadi kita, Waktu atau durasi layanan Bimbingan 
Parida Ariati, Peranan Guru Bimbingan dan Konseling dalam Pelayanan kepada Peserta Didik pada Masa Pendemi Covid-19 di SMP N 7 Muaro Jambi

dan Konseling yang di berikan selamapandemi COVID19 di SMPN 7 Muaro Jambi berjalan kurang lebih 30 menit secara online, Hambatan atau kendala dalam kegiatan layanan Bimbingan dan Konseling selama pandemi COVID-19, kendala adalah paket data yang tidak memadai, kurang paham penjelasansesuatu bimbingan ketika saat pembelajaran secara online, Pelayanan Bimbingan dan Konseling berjalan dengan efektif selama pandemi COVID-19 dari segi waktu, Saran dan kesan siswa tentang pelayanan Bimbingan dan Konseling selama pandemi COVID19, kesannya semoga Bimbingan dan Konseling bisa tetap membimbing muridnya agar bisa menjadi pribadi yang lebih baik, sarannya pelajaran yang di berikan bisa bermanfaat.

HasilDokumentasi dari Siswa Narasumber Kedua Hasil dokumentasi dari Berry Irawanselaku siswa di SMPN 7 Muaro Jambi adalah pedoman wawancara siswa, dan foto-foto hasil wawancara siswa menggunakan via online atau aplikasi WhatApp, Hasil Wawancara Siswa Narasumber Ketiga Hasil wawancara dariSerlyYunita, salah satu siswa di SMPN 7 Muaro Jambi pada tanggal 1 September 2020 waktu 11:00 Wib, penelitimenanyakan perasaan selama pandemi COVID-19 terjadi, siswa meresa tertekan, memaksa semua orang memilikikebiasaan baru untuk lebih ketat dalam hal kebersihan dan menahan dari dari berbagai macam aktivitas di luar rumah, tentu ini bukanlah hal yang mudah bagi siswa, Pelayanan Bimbingan dan Konseling sebelum pandemi COVID-19 menurut siswa berjalan baik, namun sangat berbeda saat pandemi COVID-19 terjadi membuat semua hal di batasi, Pelayanan yang siswa ketahui tentang Bimbingan dan Konseling di sekolah SMPN 7 Muaro Jambi adalah pembelajaran dalam bentuk online, Pendapat atau respon siswa tentang layanan Bimbingan dan Konseling selama pandemi COVID19, siswa merasa tertekan, karena guru Bimbingan dan Konseling selalu menganjurkan siswamenjaga kebersihan.

Bentuk pelayanan Bimbingan danKonseling yang di laksanakan selama pandemi COVID-19 adalah membantu secara darurat kepada siapa saja yang membutuhkan, Pelayanan Bimbingan danKonseling selama pandemi COVID-19 diberikan oleh Guru Bimbingan dan Konseling di sekolah, Pelaksanaan layanan Bimbingan dan Konseling selama pandemi COVID-19 adalah pada saat jam pelajaran Bimbingan danKonseling, Durasi atau waktu menerima layanan Bimbingan dan Konseling yang di berikan selama pandemi COVID-19 di SMPN 7 Muaro Jambi sekitar 30 menit, Hambatan atau kendala dalam kegiatan layanan Bimbingan dan Konseling selama pandemi COVID-19, tidak ada namun siswa merasa resah saat di rumah, Pelayanan Bimbingan dan Konseling berjalan dengan efektif selama pandemi COVID-19, karena guru Bimbingan dan Konseling masih peduli kepada siswa, Saran dan kesan kamu tentang pelayanan Bimbingan dan Konseling selama pandemi COVID19, siswa merasa tidak terbiasa dengan social distancing, semoga pandemi COVID-19 segera hilang, Hasil Dokumentasi dari Siswa Narasumber Ketiga Hasil dokumentasi dari Intan Lestari selaku siswa di SMPN 7 Muaro Jambi adalah pedoman wawancara siswa, dan foto-foto hasil wawancara siswa menggunakan via online atau aplikasi WhatApp

\section{Pembahasan}

Upaya Pelayanan Guru Bimbingan dan Konseling Selama Pandemi COVID-19 disekolah SMPN 7 Muaro Jambi Layanan Bimbingan dan Konseling yang di berikan setelah pandemi COVID-19 di SMPN 7 Muaro Jambi diantaranya sebagaimana di jelaskan dari ibu Siti Supriyah, S.Pd dan begitu juga pendapat ibu Dina Sosilawati, S.Pd guru Bimbingan dan Konseling di SMPN 7 Muaro Jambi berupa layanan bimbingan klasikal sesuai pedoman Bimbingan dan Konseling yang ada dengan beberapa tahapan pertama awalan atau pendahuluan pada tahapan ini guru Bimbingan dan Konseling memberikan salam serta memberikan penjelasan tentang topik yang akan di jelasakan, tahapan kedua adalah tahap inti atau kegiatan pada tahap ini guru Bimbingan dan Konseling menjelaskan isi materi yang di bawakan serta mengadakan sesi tanya jawab, dan pada tahapan ketiga tahap akhiran atau penutup guru Bimbingan dan Konseling serta bertanya kembali kepada siswa, untuk mengetahui seberapa siswa mengerti tentang materi yang di sampaikan. Layanan bimbingan klasikal bertujuan memberikan pengetahuan terhadap siswa meski berada di rumah baik itu untuk menjaga kebersihan, bakat, dan lain-lain. Menurut Winkel, \& Hastuti (dalam Mukhtar, Yusuf, \& Budiamin, 2016) bimbingan klasikal adalah bimbingan yang diberikan kepada sejumlah siswa yang tergabung dalam suatu satuan kegiatan pembelajaran. Sedangkan menurut menurut Fatimah, (2017) bimbingan klasikal merupakan layanan yang diberikan kepada semua siswa di dalam kelas. Menurut pendapat Mery,Berry, dan

Serly siswa di SMPN 7 Muaro Jambi tentang bentuk pelayanan Bimbingan dan Konseling yang di laksanakan selama pandemi COVID-19 mereka beranggapan baik atau positif baik itu cara ibu guru Bimbingan dan Konseling memberikan layanan bimbingan klasikal dengan baik untuk anak muridnya, dan memberikan tugas untuk mengetahui seberapa siswa paham tentang materi yang di jelaskan, resfon cepat ketika ada murid yang bertanya atau pun kurang paham dengan sesuatu hal yang berada di dalam pelajaran, serta guru Bimbingan dan Konseling bersikap untuk lebih akrab mengayomi siswa, dapat membantu secara darurat kepada siapa saja yang membutuhkan.

Menurut Maulana, \& Hamidi, (2020) pembelajaran dalam jaringan (daring) merupakan penerapan dari pendidikan jarak jauh secara online. Pembelajaran ini bertujuan untuk meningkatkan akses bagi peserta didik untuk memperoleh pembelajaran yang lebih baik dan bermutu. Selama pandemi COVID-19 menurut ibu Siti Supriyah, S.Pddan begitu juga pendapat ibu Dina Sosilawati,S.Pd, guru Bimbingan dan Konseling di SMPN 7 Muaro Jambi layanan yang di berikan kepada siswanya adalah layanan bimbingan klasikal dalam bentuk media classroom, dengan 
Parida Ariati, Peranan Guru Bimbingan dan Konseling dalam Pelayanan kepada Peserta Didik pada Masa Pendemi Covid-19 di SMP N 7 Muaro Jambi

cara guru Bimbingan dan Konseling mengatur jam untuk melaksanakan layanan, kemudian siswa-siswa kelas tertentu di perislahkan untuk memasuki classroom yang telah di sediakan sebelumnya oleh guru Bimbingan dan Konseling, kemudian pelayanan bimbingan klasikal di laksanakan untuk membahas topik tertentu yang telah di sediakan oleh guru Bimbingan dan Konseling. Siswa yang di berikan layanan Bimbingan dan Konseling pembelajaran daring atau online selama pandemi COVID-19 di SMPN 7 Muaro Jambi semua siswa baik itu kelas 7, kelas 8, dan kelas 9. Waktu atau durasi pelaksanaan layanan Bimbingan dan Konseling yang di berikan selama pembelajaran daring atau online selama pandemi COVID-19 di SMPN 7 Muaro Jambi biasanya berlangsung sekitar 30 menit dalam 1 kali daring. Pelayanan dalam bentuk pembelajaran daring atau online selama pandemi COVID-19 di anggap kurang efektif paparan dari ibu Siti Supriyah, S.Pd dan begitu juga pendapat ibu Dina Sosilawati,S.Pd guru Bimbingan dan Konseling di SMPN 7 Muaro Jambi tentang, karena sulit untuk membentuk karakter siswa secara langsung. Pendapat ini sesaui dengan paparan dari Aji, (2020) masalah yang menghambat terlaksananya efektivitas pembelajaran dengan metode daring diantaranya keterbatasan penguasaan teknologi informasi oleh guru dan siswa, kondisi guru di Indonesia tidak seluruhnya paham penggunaan teknologi, ini bisa dilihat dari guru-guru yang lahir tahun sebelum 1980-an.

Kendala teknologi informasi membatasi mereka dalam menggunakan media daring. Begitu juga dengan siswa yang kondisinya hampir sama dengan guru-guru yang dimaksud dengan pemahaman penggunaan teknologi. Jadi, peneliti mengambil kesimpulan dari pernyataan guru Bimbingan dan Konseling berserta siswa bahwa upaya pelayanan guru Bimbingan dan Konseling selama pandemi COVID-19 disekolah SMPN 7 Muaro Jambi menggunakan layanan bimbingan klasikal, layanan bimbingan klasikal bertujuan memberikan pengetahuan terhadap siswa meski berada di rumah baik itu untuk menjaga kebersihan, bakat, dan lain-lain. Pelayanan bimbingan klasikal selama pademi COVID19 dengan cara pembelajaran online atau daring dalam bentuk classroom selama 30 menit selama layanan di berikan. Namun, pembelajaran online atau daring dianggap kurang efektif karena dari segi teknologi banyak yang kurang paham untuk menggunakan, biaya, maupun untuk mendapatkan media berupa telephon siswa banyak yang meminjamnya. Respon Siswa dalam Menerima Pelayanan Guru Bimbingan dan Konseling Selama Pandemi COVID19 Pendapat dari Mery, salah satu siswa di SMPN 7 Muaro Jambi peneliti menanyakan perasaan siswa selama pandemi COVID-19 terjadi, siswamerasa biasa saja tidak banyak perubahan, setiap hari banyak tugas yang harus di kerjakan siswa, membuat siswa jarang keluar rumah selama pandemiCOVID-19, itu berbeda dengan hasilwawancara dari Berry, salah satu siswa di SMPN 7 Muaro Jambi peneliti menanyakan perasaan selama pandemi COVID-19 terjadi, siswa merasa cukup bingung, ketika ada tugas di sekolah memahami sesuatu materi lambat ketika selama pelajaran online, tidak sebaikpembelajaran secara langsung yang di jelaskan secara face to face, dan juga perbeda dari hasil wawancara dari Mery, salah satu siswa di SMPN 7 Muaro Jambipeneliti menanyakan perasaan selamapandemi COVID-19 terjadi, siswameresa tertekan, dikarenakan memaksa semua orang memiliki kebiasaan baru untuk lebih ketat dalam hal kebersihandan menahan dari dari berbagai macam aktivitas di luar rumah, tentu ini bukanlahhal yang mudah bagi siswa. Pendapat atau respon tentang layanan Bimbingan dan Konseling selama pandemi COVID- 19 menurut Serlysalah satu siswa di SMPN 7 Muaro Jambi berjalan baik, memberikan saran, dan masukkan untuk menjaga kebersihan baik berupamemakai masker ketika keluar rumah, dan selalu mencuci tangan sebelum makan. Pendapat itu juga sesaui dengan Intan Lestari salah satu siswa terhadap layanan Bimbingan dan Konseling selama pandemi COVID-19, sangat bermanfaat untuk layanan Bimbingan dan Konseling ini, karena membimbing muridnya dengan sangat sabar di pandemi COVID-19 saat ini. Berbeda dengan pendapat dari Berry tentang respon siswa tentang layanan Bimbingan dan Konseling selama pandemi COVID- 19, siswa merasa tertekan, karena guru Bimbingan dan Konseling selalu menganjurkan siswa menjaga kebersihan, Pelayanan Bimbingan dan Konseling selama pandemi COVID-19 melibatkan guru-guru Bimbingan dan Konseling, menurut pendapat dari Mery, Berry, Serly siswa di SMPN 7 Muaro Jambi.

Pelaksanaan layanan Bimbingan dan Konseling selama pandemi COVID-19 menggunakan layanan bimbingan klasikal terjadi setiap pelajaran Bimbingan dan Konseling sesuai jadwal kelas, dan terjadi setiap saat apabila siswa membutuhkan atau pun ketika kita ada masalah dengan keadaan pribadi kita. Untuk memberikan informasi kepada siswa. Sesaui dengan pendapat menurut Mukhtar, Budiman, \& Yusuf, (2016)tujuan layanan bimbingan klasikal adalah menyediakan informasi yang akurat dan dapat membantu individu untuk merencanakan pengambilan keputusan dalam hidupnya serta mengembangkan potensinya secara optimal. Waktu atau durasi siswa menerima layanan Bimbingan dan Konseling yang di berikan selama pandemi COVID-19 di SMPN 7 Muaro Jambi, selama pembelajaran Bimbingan dan Konseling 30 menit secara online atau daring. Paparan dari Berry siswa di SMPN 7 Muaro Jambi tentang pelayanan Bimbingan dan Konseling berjalan dengan kurang efektif selama pandemi COVID-19, karena menurut siswa ibu Bimbingan dan Konseling jarang memberikan layanan kepada anak murid secara daring atau di classroom. Menurut Maulana, \& Hamidi, (2020) pembelajaran dalam jaringan (daring) merupakan penerapan dari pendidikan jarak jauh secara online.

Pelaksanaan layanan Bimbingan dan Konseling selama pandemi COVID-19 pendapat dari Serlyberjalan dengan kurang efektif, karena menurut siswa ibu Bimbingan dan Konseling jarang memberikan layanan kepada anak 
Parida Ariati, Peranan Guru Bimbingan dan Konseling dalam Pelayanan kepada Peserta Didik pada Masa Pendemi Covid-19 di SMP N 7 Muaro Jambi

murid di classroom, salah satu faktornyadisebabkan waktu yang terbatas dengan guru-guru lain atau pun hambatan lain dalam menghubungi siswanya. Sedangkan menurut Intan Lestari pelayanan Bimbingan dan Konseling berjalan dengan efektif selama pandemi COVID-19 dari segi waktu, pendapat dari Merry pelayanan Bimbingan dan Konseling berjalan dengan efektif selama pandemi COVID-19, karena guru Bimbingan dan Konseling masih peduli kepada siswa. Kendala atau Hambatan Pelayanan Bimbingan dan Konseling Selama Pandemi COVID-19 Hambatan atau kendala dalam pelaksanaan layanan Bimbingan dan Konseling selama pandemi COVID-19 di SMPN 7 Muaro Jambi pendapat dari ibu Siti Supriyah, S.Pd guru Bimbingan dan Konseling di SMPN 7 Muaro Jambi adalah kuota siswa yang terbatas, dan ada beberapa siswa yang masih belum memilikihandphon, ada juga para siswa meminjam handphone milik kakaknya atau milik orang tua. Begitu juga pendapat ibu Dina Sosilawati,S.Pd salah satu guru Bimbingan dan Konseling menambahkan hambatan bisa berupa gangguan jaringan internet. Sesaui dengan pendapat menurut Aji, (2020) masalah yang menghambat terlaksananya efektivitas pembelajaran dengan metode daring diantaranya salah satunya kurang siapnya penyediaan anggaran, biaya juga sesuatu yang menghambat karena, aspek kesejahteraan guru dan murid masih jauh dari harapan.

Ketika mereka menggunakan kuota internet untuk memenuhi kebutuhanmedia daring, maka jelas mereka tidak sanggup membayarnya.

Hambatan atau kendala yang di temukan siswa dalam kegiatan layanan Bimbingan dan Konseling selama pandemi COVID-19 menurut penjelasan dari Merry, Berry, Serlisiswa di SMPN 7 Muaro Jambi tentang adalah baik berupa jaringan internet yang lelet sehingga siswa menjadi terganggu dalam pembelajaran, paket data yang tidak memadai, ada beberapa kurang paham penjelasan sesuatu bimbingan ketika saat pembelajaran secara online.

Menurut Aji, (2020) masalah yang menghambat terlaksananyaefektivitas pembelajaran dengan metode daring diantaranya salah satunya sarana dan prasarana yang kurang memadai, perangkat pendukung teknologi jelas mahal. Banyak di daerah Indonesia yang guru pun masih dalam kondisi ekonominya yang menghawatirkan. Kesejahteraan guru maupun murid yang membatasi mereka dari serba terbatas dalam menikmati sarana dan prasarana teknologi informasi yang sangatdiperlukan dengan musibah COVID-19ini. Jadi, peneliti mengambil kesimpulan dari pernyataan guru Bimbingan dan Konseling berserta siswa bahwa kendala atau hambatan pelayanan Bimbingan dan Konseling selama pandemi COVID-19 terdapat hambatan-hambatan lain berupa biaya yang kurang memadai untuk paket data dan jaringan telephon yang lelet sehingga siswa menjadi terganggu dalam pembelajaran.

\section{SIMPULAN}

Pada penelitian ini penelitimengetahui pelayanan guru Bimbingan dan Konseling selama pandemi COVID-19 disekolah SMPN 7 Muaro Jambi dengan lancar, meski banyak hambatandan kendala baik bagi guru Bimbingan dan Konseling maupun bagi siswa. Pelayanan yang di berikan guruBimbingan dan Konseling selama pandemi COVID-19 di SMPN 7 Muaro Jambi adalah layanan bimbingan klasikal,layanan ini di berikan dengan tujuan pemahaman kepada siswa selama berada di rumah baik itu materi tentang menjaga kesehatan maupun pendidikan.

Respon dan perasaan siswa dalam menerima pelayanan guru Bimbingan dan Konseling selama pandemi COVID-19 beragam sesaui dengan situasi dan kondisi siswa tersebut dan kebiasaannya. Di antaranya selama pemberian layanan ada beberapa siswa yang senang berhadapan atau bertemu secara langsungdengan guru Bimbingan dan Konseling. Kendala atau hambatan pelayanan Bimbingan dan Konseling selama pandemi COVID-19 terdapat hambatan-hambatan lain berupa adabeberapa siswa yang tidak memiliki handphone, biaya yang kurang memadai untuk paket data, dan jaringan telephon yang lelet sehingga siswa menjadi terganggu dalam pembelajaran.

\section{DAFTAR PUSTAKA}

Aji, R. H. S. (2020). Dampak Covid-19 pada Pendidikan di Indonesia : Sekolah, Keterampilan, dan Proses Pembelajaran. Jurnal Sosial \& Budaya Syar'i.

Astiti, P., Suminar, J. R., \& Fadli, A. (2020). Mengenal Covid-19 dan Cegah Penyebarannya dengan "Peduli Lindungi" Aplikasi Berbasis Android. Jurnal ResearchGate.

Rakhmawati. (2017). SistemInformasiBerbasis Web. Indonesian Journal onNetworking End.

Yusri (2013) Prosiding SeminarNasional Pendidikan FKIP Universitas Sultan Ageng Tirtayasa Vol. 2, No.1, 2019. p-ISSN 2620-9047, e-ISSN 2620-9071

Surya, M. (2011). Inovasi Bimbingan dan Konseling: Menjawab Tantangan Global. Diakses melalui www.inovasibimbingandankonselingmenjawab. html.

Yunus, (2020).MetodologiPenelitian Wilayah Kontemporel. Jogyakarta.Pustaka Belajar.

Nurhayati \& Nurfarida (2018)PengaruhTerpaanYoutube Ramayana. Ramadhan

Rahmat, A. (2018). Konstruksi Identitas Guru Bimbingan Konseling sebagai Komunikator Pendidikan.Jurnal Kajian Komunikasi.

Fatimah, D. N. (2017) .Layanan Bimbingan Klasikal dalam Meningkatkan Self Control Siswa SMP Negeri 5 Yogyakarta. Jurnal HISBAH : Jurnal Bimbingan Konseling dan Dakwah Islam. 
Parida Ariati, Peranan Guru Bimbingan dan Konseling dalam Pelayanan kepada Peserta Didik pada Masa Pendemi Covid-19 di SMP N 7 Muaro Jambi

Helaluddin, H. (2018). Mengenal Lebih Dekat dengan Pendekatan Fenomenologi: Sebuah Penelitian Kualitatif. Jurnal ResearchGate.

Maulana, H. A., \& Hamidi, M. (2020). Persepsi Mahasiswa terhadap Pembelajaran Daring pada Mata Kuliah Praktik di Pendidikan Vokasi. Equlibrium : Jurnal Pendidikan.

Mukhtar., Budiamin, A., \& Yusuf, S. (2016). Program Layanan Bimbingan Klasikal untuk Meningkatkan Self-Control Siswa. Jurnal Psikopedagogia.

Nurhayati, N., \& Nurfarida, S. (2018). Optimalisasi Peran dan Fungsi Guru Bimbingan dan Konseling dalam Implementasi Kurikulum 13. Jurnal Bikotetik.

Nuryana, A., Pawito., \& Utari, P. (2019). Pengantar Metode Penelitian Kepada Suatu Pengertian yang Mendalam Mengenai Konsep Fenomenologi. Jurnal Ensains/

Pakpahan, R., \& Fitriani, Y. (2020). Analisa Pemanfaatan Teknologi Informasi dalam Pembelajaran Jarak Jauh di Tengah Pandemi Virus Corona COVID-19. Jurnal of Information System, Applied, Management, Accounting dan Research.

Prianti, D.D. (2011). Studi Fenomenologi tentang Pengalaman Komunikasi Antar Pribadi Orang Tua-Anak terhadap Pemahaman Anak pada Norma-Norma Perilaku (Kasus pada Anak Penyandang Autisme). Jurnal Ilmiah Komunikasi.

Priyayi, D. F., Keliat, N. R., \& Hastuti, S. P. (2018). Masalah dalam Pembelajaran Menurut Perspektif Guru Biologi Sekolah Menengah Atas (SMA) di Salatiga dan Kabupaten Semarang. Jurnal Penelitian Pendidikan Biologi.

Undang-Undang Nomor 20 Tahun 2003 mengenai Sistem Pendidikan. Unicef. (2020). Pesan dan Kegiatan Utama Pencegahan dan Pengendalian COVID-19 di

Sekolah. Jurnal Unicef World Health Organization.

Wendari, W. N., Badrujaman, A., \& Sismiati, A. (2016). Profil Permasalahan Siswa Sekolah Menengah Pertama (SMP) Negeri di Kota Bogor.

Jurnal Bimbingan Konseling, Wikipedia. Pembatasan Sosial Berskala Besar Indonesia 2020.

Yuliana. (2020). Corona Virus Diseases (Covid-19). Jurnal Wellness and Healthy Magazine. 